\title{
Constructivist Grounded Theory Approach in Understanding Couples' Perceived Fairness of Gendered Division of Labor: Implications on Marxist Feminist Approach and Third Wave Feminist Thought
}

\author{
Aurora E. Araojo ${ }^{1}$, Jimmy T. Masagca ${ }^{2}$, Ernesto T. Ibardaloza ${ }^{3}$ Donna DB. Salih ${ }^{4}$, \\ Catherine G. De Leon ${ }^{5} \&$ Medie M. Lopez ${ }^{6}$ \\ ${ }^{1}$ College of Arts and Sciences-Social Science Department, Catanduanes State University, Catanduanes, Philippines \\ ${ }^{2}$ College of Arts and Sciences-Natural Science Department, Catanduanes State University, Catanduanes, Philippines \\ ${ }^{3}$ College of Arts and Sciences-Social Science Department, Catanduanes State University, Catanduanes, Philippines \\ ${ }^{4}$ College of Arts and Sciences-Social Science Department, Catanduanes State University, Catanduanes, Philippines \\ ${ }^{5}$ College of Information and Communications Technology, Catanduanes State University, Catanduanes, Philippines \\ ${ }^{6}$ Research and Development Services, Catanduanes State University, Catanduanes, Philippines \\ Correspondence: Dr. Aurora E. Araojo, College of Arts and Sciences-Social Science Department, Catanduanes State \\ University, Catanduanes, Philippines (aearaojo@csc.edu.ph)
}

Received: September 26, 2014

doi:10.11114/ijsss.v3i5.531
Accepted: November 6, 2014

Available online: August 10, 2015

\begin{abstract}
This study uses a constructivist Grounded Theory (GT) Approach guided by feminist and pro-feminism perspectives in developing a new model that analyzes the paradoxical question of why couples especially women perceive gendered division of labor as fair. Responses from agricultural partner dyads were subjected to the three-step method of the GT approach. Theoretical analysis revealed that perceived fairness of the gendered division of labor is grounded on the themes of (i) type of family upbringing, (ii) perceived physical advantage of men and perceived physical disadvantage of women, (iii) feelings of self-entitlement among men, (iv) role performance as indicator for self-worth among women, (v) sense of duty shared by the couple, (vi) open communication channels between couples, and (vii) observed family cooperation that entails delegation of household tasks to children. A new model illustrating the process of how gendered division of labor is regarded as fair between agricultural couples has been developed. Implications of this new model to Marxist Feminist Approach and Third Wave Feminism as basis for future social and policy reforms are also presented in this paper.
\end{abstract}

Keywords: gender, feminism, agricultural labor, household labor, constructivist grounded theory

\section{Introduction}

\subsection{Women in agriculture: Excerpts from the Philippine setting}

Women remain to be one of the marginalized and underrepresented sectors of our society. In spite of various efforts to put women's issues and concerns at the forefront of international, national and local agenda, gender inequality still remains. As testament to the prevailing gender disparity, a recent study (Asian Development Bank [ADB], 2013) highlighted that:

Women's labor market participation is constrained by time-consuming domestic and care responsibilities. Women often face a triple burden of caring for family, attending to domestic chores, and bearing and rearing children. These constraints begin during childhood and continue throughout the life cycle. Women often lack access to fertility control information and services that would enable them to plan if and when to have children. They are also constrained by the time spent on repetitive, tedious domestic work. This is often linked to inadequate public infrastructure for potable water, electricity, fuel, and roads as well as the availability of quality, affordable, convenient child care services. (p.49)

Tiefenthaler (1997) as cited in the same ADB study stressed that in the Philippines, women provide $84 \%$ of the total 
household time allocated to child care. Further, women in the Philippines have significantly lower employment rates than men, which in 2012 gave rise to a gender gap of 26.2 percentage points in the employment rate. The gender gap in vulnerable employment (being the sum of own-account and unpaid contributing family workers) is 6 percentage points in the Philippines. The ADB study further pointed out that women are not only more likely to be in vulnerable employment, but they are also more likely to be in the category of unpaid contributing family members, which offers the least opportunities for decent work.

Agriculture is one of the largest sectors of women's employment in the Philippines (22\%). Despite ongoing agrarian reform, when compared with men, women own less land in their own name than men and are disadvantaged through inheritance laws and land titling systems and in their ability to purchase land. Women are more likely than men to be responsible for subsistence crops and to lack access to cash crops and the resulting income. Furthermore, women receive less agriculture extension training and less credit. In addition to these, women in agriculture in the Philippines are also confronted with unpaid domestic work and care burden (ADB, 2013).

In an unpublished study by Briñes (2008) on the role of women in the abaca farming system in Catanduanes, most women farmers perform many roles in their abaca farms from planting, harvesting, stripping, drying to marketing but the bulk of their role is in the drying of abaca farmers. In a later study by Batingul (1996) on the role of women in the Rice-Based Farming System in San Isidro, Bohol as cited in the unpublished study by Briñes (2008), women played a major role in the different agricultural activities not only in the on-farm/ conventional aspect but also on the non-farm extended economic activities. Further, women were essential contributors to the social and agricultural economic well-being of their families both in on-farm and non-farm activities. In another unpublished study by Manalalo (1999) on the role of women and participation in the self-help community development program in Dasmariñas, Cavite as cited in the same unpublished study by Briñes (2008), the role of women were classified as conventional roles, which included their responsibility of managing the home and attending to the needs of the family, and social development roles such as learner, follower, teacher, health care provider, leader, and consultant.

In another study by Gaddi (2013), the contribution of rural women in the different aspects of farm work was examined and was considered as invisible and unrecognized given that women's work can be found in the 'Both' column but it is not indicated in the 'Female' column as shown in Table 1 below.

Table 1. Gender division of labour in rice production

\begin{tabular}{|c|c|c|c|}
\hline Farm Activities & Female & Male & Both \\
\hline Land preparation & & $\mathrm{x}$ & \\
\hline Seedbed preparation & & $\mathrm{x}$ & \\
\hline Ploughing & & & $\mathrm{x}$ \\
\hline Harrowing & & & $\mathrm{x}$ \\
\hline Leveling & & $\mathrm{x}$ & \\
\hline Care of seedlings & & $\mathrm{x}$ & \\
\hline Pulling and bundling of seeds & & & $\mathrm{x}$ \\
\hline Planting/ Transplanting & & & $\mathrm{x}$ \\
\hline Irrigation & & & $\mathrm{x}$ \\
\hline Care of irrigational canal & & $\mathrm{x}$ & \\
\hline Care of crops & & & $\mathrm{x}$ \\
\hline Mechanical weeding & & & $\mathrm{x}$ \\
\hline Manual weeding & & & $\mathrm{x}$ \\
\hline Fertilizer application & & & $\mathrm{x}$ \\
\hline Spraying & & & $\mathrm{x}$ \\
\hline Picking of snails & & & $\mathrm{x}$ \\
\hline Harvesting & & & $\mathrm{x}$ \\
\hline Threshing & & & $\mathrm{x}$ \\
\hline Hauling & & & $\mathrm{x}$ \\
\hline
\end{tabular}




$\begin{array}{lcc}\text { Drying } & & \mathrm{x} \\ \text { Other farm activities } & & \mathrm{x} \\ \text { Food preparation } & \mathrm{x} & \\ \text { Accessing capital } & \mathrm{x} & \end{array}$

Source: Bureau of Agricultural Statistics, 2004 (cited in FAO Fact Sheet Philippines and the study of Gaddi, 2013)

Gaddi (2013) further argued that although agriculture continues to be the backbone of a developing country like the Philippines, agriculture production nowadays is still a family affair. However, family members, mostly women and children, remain to be unpaid farm workers in traditional farming systems.

\subsection{Gendered division of labor and the paradox of fairness}

Gender stereotypes result to skewed expectations, regardless of whether it is implicit or explicit, between and among couples. Males are generally expected and even encouraged to exercise dominance over their female counterparts, while obedience and understanding are required from women. It is also generally accepted for men to look for employment outside the home, while there has still been some resistance against women who decide to undertake the role of provider particularly if she will be the one to leave home.

Extending the effect of gender stereotyping further, in spite of the increasing number of women who join their husbands in performing economic activities in order to provide for their family, women still bear the "double burden" of working to earn for their family's keep and at the same time trying to meet society's (and even her partner's) expectation to care for her family (ADB, 2013). In spite of these, most women prefer to bear the burden silently.

Perplexed by this phenomenon, researchers attempted to provide an explanation as to why women, in spite of carrying this 'double burden', still regard this arrangement as fair. Blair (1998), as cited in the work of Nameda (2013), observed that psychological research on the division of household work has focused on the linkage between perceived fairness and the division of household work with the main issue as to why some women do not perceive the objectively unfair division as unfair. Blair (1998) further stressed that despite women's increased participation in the paid workforce, couples continue to perform quantitatively unbalanced division of household work. Dixon and Wetherell (2004) and Fuwa and Tsutui (2010) as cited in the same study by Nameda (2013) were all in agreement that this question on why some women perceive this gendered work relation as fair is a crucial paradox to be resolved.

In an attempt to shed light on this matter, several research studies have been conducted that resulted into three proffered frameworks that attempted to explain why women hold this view: (a) time availability, (b) resource dependence, and (c) gender ideology (Bianchi, Milkie, Sayer, \& Robinson, 2000). Athough the arguments raised by the first two frameworks may be valid for some couples, unlike the gender ideology framework, they cannot be used as an explanation on why women perceive the unfair division of labor as fair particularly in agricultural households where both couples are engaged in farming activities.

Time Availability Framework argues that hours spent in paid employment presumably affect the division of household labor because the partner who has the most time available after work will do the most at home (Shelton \& John, 1996). However, in some local communities for developing countries such as the Philippines where patriarchy is highly pronounced, husbands who are unemployed refuse to perform household chores as they consider these as unmanly tasks. Their free time is mostly devoted to other activities that have nothing to do with household chores as observed in most household communities.

In contrast, Resource Dependence Framework bases its argument on the couples' relative resources and claims that the partner with fewer economic resources (e.g. income) has little power and cannot "win" negotiations about who does the household chores (Becker, 1991 \& Brines, 1993 \&). However, this framework is not applicable to the same local communities wherein unemployed husbands have the tendency to resent their wives' financial capacity, which is perceived as supremacy, over them.

Providing a seemingly more valid argument, Gender Ideology Framework contests the assumption of economic theories that decisions about the division of labor are gender neutral, rational and driven by constraints rather than fixed prefences. This framework further contests these assumptions by proposing that household labor is intertwined with beliefs about certain behaviors being typically male or female (Poortman \& Van Der Lippe, 2009; Berk, 1985; De Vault, 1991). Hence, the Gender Ideology Framework presents a more credible argument than the first two frameworks.

Expounding further on the capability of gender ideology to explain why women view this unequal distribution of labor as such, Nameda (2013) incorporated the Procedural Justice Theory with gender theory and included the perceptions of males in his study. Results revealed that in performing the division of labor, not only "participation," such as expressing 
one's opinion, but also "treatment with dignity and respect," such as acknowledging appreciation, is an important aspect of perceiving fairness. However, the importance of the procedural and interactive aspects in performing the division of labor was only true for women.

Acknowledging the limitations of his study, Nameda (2013) recommended for future research to examine couples' marital interaction in the performance of household labor and to use scales that measure the participants' sense of fairness for themselves, for their partner, and for both themselves in gaining a clearer understanding of this phenomenon.

\subsection{Qualitative research with partner dyads: Is a feminist approach useful?}

Foucault (1984) and Grimshaw (1993) as cited in the work of Mann and Huffman (2005) stated that recent developments in social thought have heightened our awareness of how theories of emancipation can be blind to their own dominating, exclusive and restrictive tendencies and that feminism is not innocent of such tendencies. In this paper, we echo Mann and Huffman's (2005) argument that within movements of emancipation, counter discourses that produce new knowledge, speak new truths, and constitute new powers may occur as a form of resistance against a current ideology's growing inadequacy.

In the work of Peters, Jackson and Rudge (2007), the value of feminist approaches when undertaking narrative-based research with partner dyads and when researching sensitive issues are underscored. By using qualitative methodologies guided by feminist perspectives, they argue that feminist narrative methods have the capacity to contribute to understandings of human experience for individuals and couples, despite differences in gender or sexuality, by highlighting individual as well as shared experiences within partnerships. By partner dyads, we use it to refer to heterosexual relationships that are the subject of this study. By labor, we refer to duties and tasks usually carried out by couples in the internal and external home environment. By feminist approaches, we mean Marxist Feminist Perspectives and Third Wave Feminist Thoughts (Mann and Huffman, 2005; Zimmerman, McDermott and Gould, 2009).

We argue in this paper that although the three theories mentioned in the preceding section of this paper may be applicable to dual-earning and highly-educated couples, its applicability to rural agricultural households that are non-dual earners and non-highly educated may not hold true. For instance, agricultural women also spend their time in the fields to help their husbands during farming activities (Batingul, 1996; Briñes, 2008) and resource dependence by the wife to the husband is eliminated considering that the wife also engages in other non-farming activities to help augment the family income (Briñes, 2008). In addition, women abaca farmers also perform farming tasks that may be considered as appropriate for males only (Briñes, 2008).

In this paper, we adopt a constructivist Grounded Theory (GT) Approach guided by feminist and pro-feminism perspectives in developing a new model that explains this phenomenon. Implications of this new model to Marxist Feminist Approach and Third Wave Feminism are also presented as basis for future social and policy reforms.

\section{Method}

As initially developed by Corbin and Strauss (1990), Grounded Theory (GT) is a general methodology for developing theory that is grounded on in data that was systematically gathered and analyzed. The continuous interplay between analysis and data collection enables theory formulation during actual research.

We decided to adopt GT Approach enriched by a constructivist perspective to examine agricultural couples' perceived fairness on the gendered division of labor. Ackerly and True (2010) as cited in the study of Hall (2014) described the fit between a feminist research ethic and grounded theory methodology as follows:

Grounded theory is a form of structured inquiry that is useful for studying questions that themselves have been concealed by dominant discourses, conceptualization, and notions of what questions are important. By design, then, grounded theory is a research design that enacts a feminist research ethic. (p. 204)

As stated by Hall (2014), constructivist GT stands out among the various strands of GT for its reflexivity about the role of the researcher in engagement with data, which lends itself to a feminist research ethic. It defines theory as interpretative and understands the researcher as an integral part of the data.

Collection of data was done during a three-month period of observation and participation in a rural village in the municipality of Virac, Catanduanes, Philippines, and included semi-structured interviews and focus group discussions (FGDs). Throughout this study, we were guided by the principle that GT and analysis should be grounded in the data, not the single perspective of the academic (Ackerly and True, 2010; cited by Hall, 2014). Although we maintained our feminist and pro-feminism orientations, we made sure that questions during interviews and FGDs were neutral so as not to create unnecessary tension in the study area, which has largely retained its patriarchal orientation in spite of recent efforts by the municipal local government unit to promote gender and development awareness in the area. As another 
measure to capture the data in full during the data gathering procedure, verbatim notes and transcripts were copiously maintained. Field notes describing actual observations were also made. Head notes were made, filed and coded separately.

\subsection{Participants and Procedure}

Purposive and snowball or chain sampling methods were used to identify the respondents of the study. To facilitate a smooth point of entry into the local community, permission to conduct the study was secured from the village chief (barangay captain). Upon approval, the village chief gathered the members of their local farmer organization, which became the first wave of respondents for the study. Subsequent respondents were then identified through the initial wave of respondents.

Fifteen agricultural partner dyads were the respondents of this study ( $\mathrm{n}=30$ individuals). The average age for female respondents is 53 while the average age for male respondents is 55 . The ages ranged from 38 to 70 years for males, while it is 35 to 75 years for females. In terms of education, only two (2) out of the 15 female respondents were able to earn a college degree. The rest were able to reach high school level $(n=8)$ and elementary level $(n=5)$ only. None of the male respondents were able to finish their college degree. Ten were able to reach high school level while five (5) were unable to finish elementary level. All of the respondent partner dyads in this study are married with a range of 19 to 51 years of marriage. All of the couples have children. The average number of children per couple is five with the age range of 19 to 50 years of age. All of the partner dyads have been engaged full-time in rice farming and vegetable production for an average of 27 years with a range of four (4) to 48 years.

Given that constructivist GT approach employs theoretical sampling, we collected and analyzed data until the point of theoretical saturation was reached. FGDs were first conducted among husbands and wives in separate groups and then as couples. Participants were asked four (4) central questions during the course of the data gathering period: (1) 'What tasks do perform inside and outside your home as husband/ wife'?; (2) 'How about your spouse?'; (3) 'How will you describe your relationship with your spouse?'; and (4) 'Do you think that this division of labor between you as a couple is fair for you both?'. Structured and unstructured individual interviews were also conducted to validate and substantiate responses gathered during the FGD. We also maintained ethnographic data such as observations and experiences through field notes.

Given that what is being examined under this study is a sensitive issue, interviews were not recorded. Rather, notes were immediately written after the conduct of an interview. During FGDs, note-taking was also done. Although consent was requested from and given by the respondents before their participation in the study, we proceeded cautiously with the study so as not to disrupt the social environment of the group being studied. Furthermore, confidentiality of the respondents' responses and identity were maintained at all times.

\subsection{Three-Step Method of GT for data analysis}

Strauss and Corbin's (1998) three-step method of grounded theory was used to analyze the data gathered. Although we remain guided by a constructivist approach, by using this three-step method, we believed that systematic theoretical analysis could be done through this and a new theory could be generated to understand why agricultural couples, particularly women, regard gendered division of labor as fair.

The first step in data analysis under this approach is open coding. It consists of breaking down the data by identifying and labeling different concepts/ phenomena that are grounded within it. The concepts are compared for their similarities and differences and then are grouped together to form categories and sub-categories. The categories are known as open codes whilst the subcategories include the relevant information that make up the open codes. During this process the researcher writes memos to aid in the generation of a theory later on.

The second step, axial coding involves linking categories together. By looking at the sub-categories of a category it is possible to come up with its conditions if these are similar to that of another then these would link together to form an axial code - a statement which summarizes the information from all connected categories.

The last step, selective coding, involves the incorporation of axial codes to come up with one central category or a theory of the phenomena being investigated that successfully include all relevant categories from both open-coding and axial coding. (Williams and Reid, 2007).

\section{Results}

\subsection{Actual Division of labor between Couples}

Partner dyads in the study generally performed the following division of labor as shown in Table 2 on the succeeding page (type/ category of work performed are modified from the categories used by Nameda (2013) to conform to the local context of the study area): 
Table 2. Division of labor between respondent partner dyads

\begin{tabular}{|c|c|c|c|}
\hline Type of Work & Wife & Husband & Other Actors \\
\hline \multicolumn{4}{|l|}{ Basic Household Chores } \\
\hline - Meal Preparation & $\mathrm{x}$ & $\mathrm{x}$ & \\
\hline - Washing Clothes & $\mathrm{x}$ & $\mathrm{x}$ & \\
\hline - Organizing/ Folding Washed Clothes & $\mathrm{x}$ & $\mathrm{x}$ & \\
\hline - Ironing Clothes & $\mathrm{x}$ & & \\
\hline - Cleaning the dining area after meals & $\mathrm{x}$ & & $\begin{array}{l}\text { Children } \\
\text { (girls and boys) }\end{array}$ \\
\hline - Washing the dishes & $\mathrm{x}$ & $\mathrm{x}$ & Children (girls) \\
\hline - Cleaning the toilet and bathroom & $\mathrm{x}$ & & Children (girls) \\
\hline - Garbage disposal & $\mathrm{x}$ & $\mathrm{x}$ & $\begin{array}{l}\text { Children } \\
\text { (girls and boys) }\end{array}$ \\
\hline \multicolumn{4}{|l|}{ Child-rearing } \\
\hline - Teaching discipline & $\mathrm{x}$ & $\mathrm{x}$ & \\
\hline - $\quad$ Playing with the children & $\mathrm{x}$ & $\mathrm{x}$ & \\
\hline $\begin{array}{l}\text { - Taking care of the children's things such as clothes } \\
\text { and school items }\end{array}$ & $\mathrm{x}$ & $\mathrm{x}$ & \\
\hline \multicolumn{4}{|l|}{ Agricultural Work } \\
\hline - Ploughing the field & $\mathrm{x}$ & $\mathrm{X}$ & $\begin{array}{l}\text { Paid farm helper for } \\
\text { those that can afford }\end{array}$ \\
\hline - Looking after the carabao & $\mathrm{x}$ & $\mathrm{x}$ & \\
\hline - $\quad$ Planting/ Sowing & $\mathrm{x}$ & $\mathrm{x}$ & $\begin{array}{l}\text { Paid farm helper for } \\
\text { those that can afford }\end{array}$ \\
\hline - Weeding & $\mathrm{x}$ & $\mathrm{x}$ & \\
\hline - Harvesting & $\mathrm{x}$ & $\mathrm{x}$ & \\
\hline \multicolumn{4}{|l|}{ Other livelihood activities/ activities as alternative } \\
\hline \multicolumn{4}{|l|}{ sources of income } \\
\hline $\begin{array}{l}\text { - Selling the harvest in the market } \\
\text { - } \quad \text { Tricycle as paid public transport }\end{array}$ & $\mathrm{x}$ & $\mathrm{x}$ & \\
\hline
\end{tabular}

Seventeen out of the 18 types of work identified are being performed by the female respondents. On the other hand, only 14 types of work are being performed by the male respondents. Ironing clothes, cleaning the dining area after meals, cleaning the toilet and bathroom, and selling the harvest in the market are considered to be tasks for females only. Although both couples play an active role in child-rearing, their children also follows the same pattern of gendered division of labor. Except for cleaning the dining area after meals and garbage disposal, which are performed by both their female and male children, only girls wash the dishes and clean the toilet and bathroom.

\subsection{Themes leading to the perceived fairness of gendered division of labor}

Themes such as type of upbringing from family of origin, perceived physical advantage (by the husband) that also leads to a sense of entitlement by the husband, perceived physical disadvantage (by the wife) that makes the wife regard her role performance in the family as indicative of her self-worth, sense of duty (for both couples), and other related concepts such as open channels of communication (between couples and within the family), family cooperation, and external sources of support for the couple can be linked to the core category of perceived fair division of labor between couples even though the arrangement is regarded by gender advocates and scholars as generally unfair for the wife. Figure 1 on the succeeding page illustrates the new model developed regarding the phenomenon of agricultural couples perceiving gendered divison of labor as fair. 


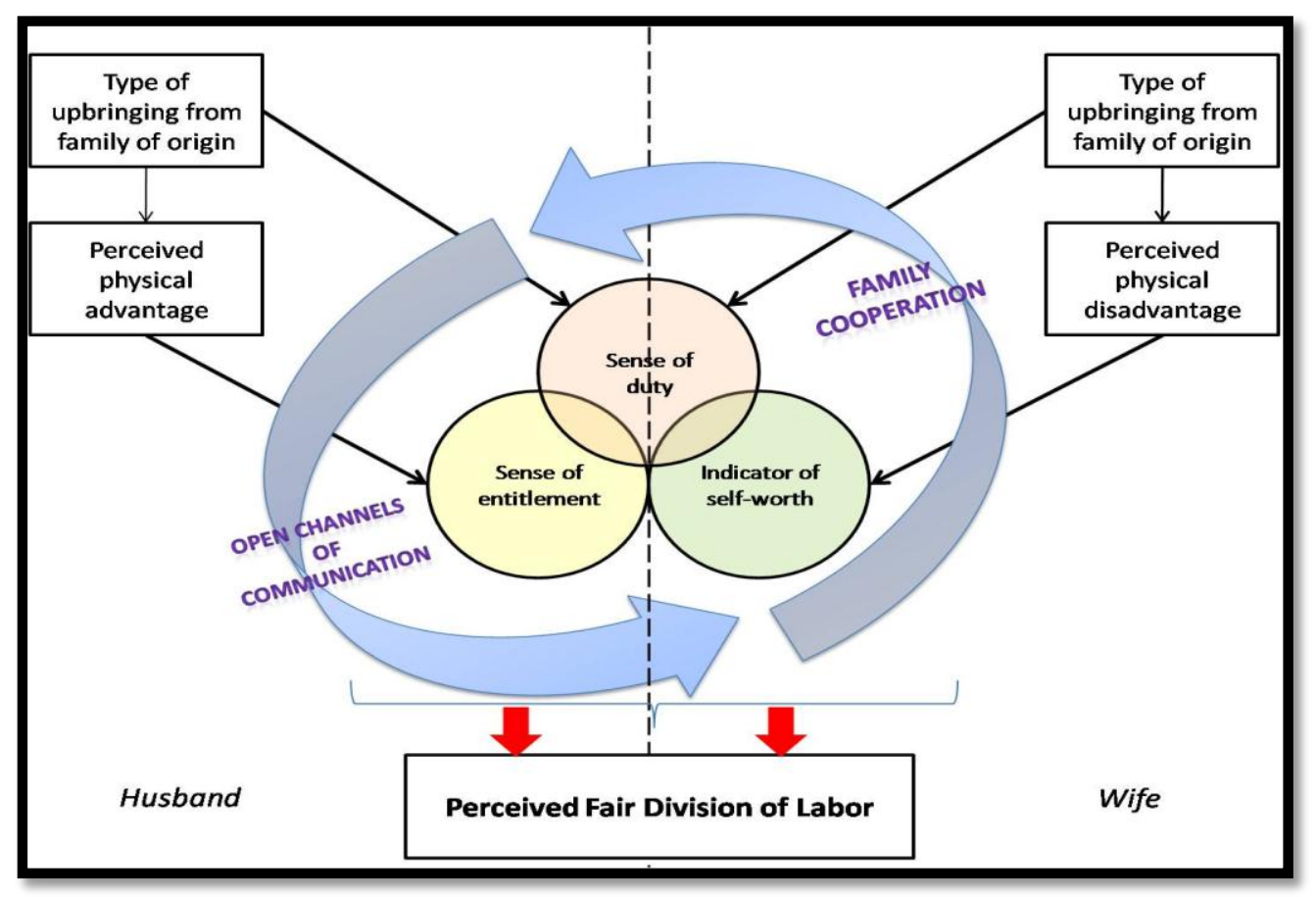

Figure 1. New model illustrating how gendered division of labor is regarded as fair between agricultural couples using the constructivist GT approach

\subsubsection{Type of Upbringing from Family of Origin}

Both couples in this study refer to their experiences from their birth family in gauging the fairness of their division of labor ('My parents had this kind of arrangement...'; 'My father was the one working on the rice fields even though my mother would also help at times, but I remember my mother being the one to take care of us, cooking meals, etc.'; I feel like it was a long time ago but I remember that both my father and my mother attended to the fields. However, when it comes to doing household chores, my mother is the one in-charge and we as children are also required to help.'). All respondent couples admitted that their current parenting roles and styles were influenced by how they were brought up by their families ('My father was a very serious man. He does not speak much but he was the family's disciplinarian. When my mother and he would come home from the fields after a day of harvest, my mother was still the one who prepared the family dinner. However, when we became older, our mother taught my sisters how to cook and clean the house.'; 'My father was the discplinarian and we would always run to our mother whenever he would get mad.'; and 'My father was always in the rice fields and my mother would bring him his lunch. During harvest time, we would all go the fields together with our mother and help.')

\subsubsection{Perceived physical advantage and sense of entitlement (of the husband)}

Although modern feminist science challenges the biological essentialist view of gender (Code, 2000) particularly on the proposed theory on the innate biological difference between men and women's minds (Fine, 2010; Bern, 1993; and Sterling, 1992), all of the female respondents acknowledged the physical superiority of their partners ('His work in the fields is heavy. It's back-breaking work.'; 'Being out in the rice fields requires endurance and I understand why my husband is the one doing this type of work for our family.'). Other respondents further highlighted the physical difference between women and men ('As a couple, we each have our own strengths and weaknesses. I work in the field though she would also help me whenever she can but I am the one mostly doing the work.) However, an outlier among the female respondents was noted thus the red ' $\mathrm{x}$ ' mark on Table 2 ('I plow the field. When my husband cannot work on the field because he has to go someplace or he is not feeling well, I tend to our rice field. I will get the carabao and then go on with ploughing. It's hard but I understand why I have to do it for my family.) The implication of this outlier will be discussed in the succeeding sections.

\subsubsection{Perceived physical disadvantage and role performance as indicator of self-worth (of the wife)}

In relation to the preceding section, it is evident that majority of the female respondents acknowledged their husbands' advantage in terms of physical strength. Given this, they expressed their felt need to compensate for their husbands' perceived physical advantage ('My husband is always out working in the fields so I make sure that when he comes home, the food is ready.'; 'Though I help my husband in the field, I try to make it a point to prepare the food that we will bring 
when we go to the rice fields. He does most of the heavy task so I try to help him in any way I can.'). When asked whether she perceives that she and her husband are of equal strength considering that she can also plow the field, the outlier responded that she does not think so ('It just happened that I know how to do it but if my husband had been there, he will be the one to do it for me. Plus, he has been doing the hard work for many years now.')

\subsubsection{Sense of duty (for both couples)}

All of the respondents believed that it is their duty as husband and wife and as parents to care for their family, and that the best way to do this is to divide labor between them. The male respondents felt that because of their perceived physical advantage over their wives, they need to do more for their family ('I am the head of our family so it is my duty to provide for them. '). Relatedly, the female respondents, acknowledging their perceived physical disadvantage, felt that it is also their role as wives and mothers to care for their family ('As a wife, I need to be supportive of my husband. As a mother, it is my duty to take care of our children.'). However, both couples no longer hold the view that men should be the one to provide for the financial needs of the family while women should be confined at home to care for the children. All of the respondents acknowledged that providing and caring for the family is a duty of both husband and wife ('I no longer believe that men should be the one to work while women should stay at home. Times are difficult and we need to work together to ensure that we have food for our family.')

\subsubsection{Other Intervening Themes}

All respondents of the study indicated that open channels of communication between couples and within the family, as well as the observance of family cooperation enhances their perceived sense of fairness in the division of labor. Most of the respondents stated that they did not explicitly discuss their current division of labor, while the remaining respondents did at the time of their marriage. In spite of these implicit and explicit arrangements, all respondents agreed that they maintain the same work division as their partners has not voiced any objection to this system ('I don't recall that we talked about who will be in charge of whom when we got married. I think it just came naturally that he was the one working in the fields while I take care of the children. However, we all work together as a family particularly during harvest season. I make it a point to help my husband during this time and also my children when they are not in school.'; 'When we got married, we talked about how we wanted our family to be. I am lucky that my husband listens also to what I say.'; 'My wife tells me whenever there is something bothering her. I am not very expressive of my moods but my wife can sense what is on my mind. I also know when she has something to tell me so we would go outside our house to talk about it.'; 'It's important in a marriage to talk about problems. I tell my husband whenever I am not in favor of something. Family decisions are also made between us.'; 'We have our disagreements but we try to resolve our differences.').

Because all of the respondents' children are already grown-up, the couples emphasized that cooperation in a family is very important ('We taught our children the value of hard work. I taught them (daughters) how to cook and to help me in the household chores.'; 'After meals, I no longer worry about the dishes because my children cleans the dining table and washes the dishes afterwards. However, I also wash the dishes and even wash the clothes when my wife is away or unable to do these tasks.')

\section{Discussion}

In spite of women respondents accounting for 17 out of 18 types of work and their husbands responsible only for 14 out of 18 tasks, all respondent couples agree that this division of labor is fair. Several themes leading to the unifying theory on why these couples, particularly the women, regard this gendered division of labor as fair emerged from this study.

Foremost is the type of upbringing from the respondent's family of origin. All respondents of the study admitted that their current roles and parenting styles were heavily influenced by their parents. As evidenced by their responses and the observed performance of tasks, all the couples were unconsciously repeating the work arrangement they have previously observed from their parents. From this, two types of themes further emerged: perceived physical advantage and sense of entitltment of the husband, and perceived physical disadvantage and role performance as indicator of self-worth for the wife. The male respondents are convinced of their supremacy over their wives in terms of physical strength hence performed all of the heavy tasks. Although they also help in caring for the children and perform other lighter chores that are mainly performed by women, they refuse to perform four types of tasks that they believe should only be for women (see Table 2). In response, all female respondents believe that their husbands are superior in strength and thus made up for this by performing tasks that are perceived to be for women only even though they also perform

From these two diverging themes emerged the central category or theory about the phenomenon that is both shared by the respondent couples: a sense of duty to care for their family. However, all couples believe that the role of provider is no longer limited to the husbands but to the wives as well. They attributed the need for both couples to earn a living for their family on the difficult financial conditions they feel is prevalent today. 
Reinforcing the perceived fairness on gendered division of labor are the themes on open channels of communication and family cooperation. All female respondents who stated that they regard their division of labor as fair also responded that they are able to talk to their husbands about family concerns whenever they need to. Furthermore, all of the couples have younger children that are able to help in the household chores (see Table 2).

Interspersing the above results with feminist ethnographic data, respondents observe a gendered division of labor as evidenced by the observed work schedule performed by the respondents. However, they unanimously agree that this arrangement is fair for them.

\section{Conclusion}

Perceived fairness of the gendered division of labor entails several concepts that led to this view. Foremost is the family upbringing, followed by perceived physical advantage of men and perceived physical disadvantage of women that in turn led to feelings of self-entitlement for the former and role performance as basis of self-worth for the latter. Both couples developed a sense of duty in their marital roles for the sake of their family. Reinforced by an open communication system between couples and observed family cooperation that translates to delegation of household tasks to their children, couples particularly women regard this arrangement as fair.

Although both couples are engaged in agricultural activities, the wives feel the need to compensate for their perceived physical disadvantage by undertaking nurturing/ caring roles in the family. However, both also acknowledged the importance of changing gender roles to adapt to the current economic changes being experienced by the family.

In the new model developed, socio-cultural determinants, procedural justice theory interspersed with gender role ideology, and couples' interaction shaped the way couples perceive this division as fair. Further, although Marxist Feminist views may still hold true today, Third Wave Feminist Thoughts which take into account a non-essentialist view on women and men are necessary should we want to truly divide the gender gap for inclusive development.

\subsection{Implications on Marxist Feminist Approaches and Third Wave Feminism}

In an attempt to provide a comprehensive analysis of this phenomenon, we offer the following arguments based from the model and in relation to Marxist feminist approach and third wave feminist thought:

First, the identified concepts on perceived physical advantage/ disadvantage between the couples and the resulting concept of feelings of entitlement/ basis for self-worth are reflective of what Marxist Feminism has tried to reverse (Mann and Huffman, 2005). Based from the ideology of Karl Marx and Freidrich Engels, gender inequality is rooted in the capitalist structure of society. However, the extremes depicted in this perspective do not reflect the actual situation observed in this study. Gendered roles in relation to unequal social structures are observed although in a subtle level.

Second, Marxist Feminism was unable to take into account the different socio-cultural determinants of gender bias prevalent in a rural community within the context of a developing nation. Rural communities, as observed in the study site, unconcsciousy consider gender stereotyping as the norm. They perceive this arrangement as crucial for the family to survive. Based on the responses gathered validated by ethnographical observations, there was no trace of the man-oppressing-a-woman as wives were able to express their views on household matters. In spite of the perceived gender difference due to physical strength, all of the respondent couples agreed that the role of family provider is not only confined to the males but should rather be shared between the couple given the economic conditions present today.

Third, we noted that although male respondents were sharing in basic household chores, the observed behavior of delegating these tasks to their children particularly females is also another area of concern. We therefore argue that interventions to address the gender divide should begin at home. Hence, we turn to Third Wave Feminism.

Third wave feminists argue that this perspective seeks to end relationships of domination and oppression by beginning with individual understanding of power relations. Echoing Paulo Freire's Pedagogy of the oppressed (1993, p. 44) as cited by Zimmerman, McDermott and Gould (2009), third wave feminists acknowledges that the struggle to end relations of domination begins with the oppressed. It invites those who feel oppressed and marginalized to share their experiences. In this sharing, the face or the subjectivity of that person who has been objectified is revealed. Relating this concept to the studied group, the homogeneity of women as claimed by second wave feminism cannot be applied in this situation. The studied group possesses socio-economic and cultural characteristics that are different from the women that have been the subject of second wave feminism.

In addition to this view, we argue against Connell (2011) as cited in Peters, Jackson and Rudge's (2007) study that feminist research should be about women and undertaken by women. We believe that the oppressive social structure does not affect women alone but rather men as well. As such, it is imperative that we work closely with both women and men to better understand gender inequality and work effectively towards bridging the gender divide. 


\section{Acknowledgements}

We would like to express our profound gratitude to the following: our respondent couples for trusting us enough to participate in the study; local barangay officials of the study site for patiently attending to our concerns; Catanduanes State University (CSU) R\&D Services Staff for their invaluable assistance; the CSU Technical Evaluation Committee for their substantial recommendations; the CSU Management for their support in making this study realized; and most importantly, to the One above for keeping us sane during those tumultuous period of writing this paper.

\section{References}

Asian Development Bank. (2013). Gender inequality in the labor market in the Philippines. Retrieved from http://www.adb.org

Batingul, R.V. (1996). The role of women in the Rice-Land Farming System in San Isidro, Bohol: Its implications to countryside agricultural development. University of Bohol, Tagbilaran City.

Becker, G. S. (1991). A treatise on the family: Enlarged edition. Cambridge, MA: Harvard University Press.

Berk, S. F. (1985).The gender factory: The appointment of work in American Households. New York: Plenum Press.

Bern, Sandra L. (1993). The lenses of gender: transforming the debate on sexual inequality, Yale University Press, ISBN 0-300-05676-1, 6.

Bianchie, S. M., Milkie, M. A., Sayer, L. C., \& Robinson, J. P. (2000). Is anyone doing the housework? Trends in the gender division of household labor. Social Forces, 79, 191-228.

Blair, S. L. (1998). Work roles, domestic roles, and marital quality: Perceptions of fairness among dual-earner couples. Social Justice Research, 11,313-335.

Brines, J. (1993).The exchange value of housework. Rationality and Society, 5, 302-340.

Briñes, L.V. (2008). The role of women in Abaca Farming System in Catanduanes (unpublished). Catanduanes State Colleges, Philippines.

Bryson, V. (2004). Marxism and feminism: Can the 'unhappy marriage' be saved?, Journal of Political Ideologies, 9(1), 13-30. http://dx.doi.org/10.1080/13569310320000167454

Code, L. (2000). Encyclopedia of feminist theories. Taylor \& Francis, 89. ISBN 0-415-13274-6.

Coltrane, S. (2000). Research on household labor:Modeling and measuring the social embeddednessof routine family work. Journal of Marriageand Family, 62, 1208-1233.

Cooney, A. (2011). Rigour and grounded theory. Nurse Researcher, 18(4), 17-22.

Corbin, J., \& Strauss, A. (1990). Grounded theory research: Procedures, canons, and evaluative criteria. Retrieved from http://sites.duke.edu/niou/files/2014/07/W10-Corbin-and-Strauss-grounded-theory.pdf

Cresswell, J. W. (2007). Qualitative inquiry and research design: Choosing among five approaches. Sage Publications, Inc. ISBN 978-1-4129-1607-3 (pbk)

De-Vault, M. L. (1991). You see the need perhaps more clearly than I have. Journal of Family Issues, 22, 328-357.

Dixon, J., \& Wetherell, M. (2004). On discourse and dirty nappies: Gender, the division of household labour and the social psychology of distributive justice. Theory and Psychology, 14, 167-189.

Fausto-Sterling, A. (1992). Myths of Gender: Biological Theories About Women and Men. New York, New York: BasicBooks. ISBN 0-465-04792-0.

Feminism. (n.d.). In Wikipedia. Retrieved September 5, 2014, from http:// http://en.wikipedia.org/wiki/Feminism

Fine, Cordelia (2010). Delusions of Gender: How Our Minds, Society, and Neurosexism Create Difference. W. W. Norton \& Company

Freire, P. (1993). Pedagogy of the oppressed [30 ${ }^{\text {th }}$ Anniversary Edition]. Retrieved from https://libcom.org/files/FreirePedagogyoftheOppressed.pdf

Fuwa, M., \& Tsutsui, J. (2010).A cross-national comparisonof the perceived fairness of the divisionof household labor.Japanese Journal of Family Sociology, 22, 52-63. (In Japanese with English abstract.)

Gaddi, R. S. (2013). Gendered work relations systems in agriculture: Implications to women's participation, good governance and sustainable development. Philippine Journal of Social Development, 5, 1-27.

Hall, K. Q. (2014). Developing A Dual-Level Capabilities Approach: Using Constructivist Grounded Theory And Feminist Ethnography To Enhance The Capabilities Approaches. Journal of Ethnographic \& Qualitative Research, 
$8(3), 128-143$.

Hawkins, A. J., Marshall, C. M., \& Allen, S. M. (1998).The orientation toward domestic labor questionnaire: Exploring dual-earner wives' sense of fairness about family work. Journal of Family Psychology, 12, 244-258.

Herr, R. (2014). Reclaiming Third World Feminism: or Why Transnational Feminism Needs Third World Feminism. Meridians: Feminism, Race, Transnationalism, 12(1), 1-30. http://dx.doi.org/10.2979/meridians.12.1.1

Holmgren, L., \& Hearn, J. (2009). Framing 'men in feminism': theoretical locations, local contexts and practical passings in men's gender-conscious positionings on gender equality and feminism. Journal of Gender Studies, 18(4), 403-418. http://dx.doi.org/10.1080/09589230903260076

Jacka, T. (2006). Approaches to Women and Development in Rural China. Journal of Contemporary China, 15(49), 585-602. http://dx.doi.org/10.1080/10670560600836564

Jenkins, K. (2014). 'That's not philosophy': feminism, academia and the double bind. Journal of Gender Studies, 23(3), 262-274. http://dx.doi.org/10.1080/09589236.2014.909720

Manlalo, A. (1999). The role of women in the Self-Help Community Development Program.De La Salle University, Dasmariñas, Cavite.

Mann, S., \& Huffman, D. J. (2005). The Decentering of Second Wave Feminism and the Rise of the Third Wave. Science \& Society, 69(1), 56-91.

Marcuse, H. (2006). Marxism and Feminism. Differences: A Journal of Feminist Cultural Studies, 17(1), 147-157. http://dx.doi.org/10.1215/10407391-2005-007

NAMEDA, A. (2013). Sense of fairness in the division of labor in close relationships: Procedure and gender role ideology. Japanese Psychological Research, 55(1), 33-44. http://dx.doi.org/10.1111/j.1468-5884.2012.00539.x

Ohno, S., Taya, Y., \& Kashiwagi, K. (2003). Factorsrelevant to men's involvement in householdlabor.Human Developmental Research, 17, 53-68. (In Japanese with English abstract.)

Organisation for Economic Co-operation and Development (OECD). 2012. How Do People in the Asia/ Pacific Region Spend Their Time? Society at a Glance: Asia/ Pacific 2011. Paris.

Peters, K., Jackson, D., \& Rudge, T. (2008). Research on couples: are feminist approaches useful?. Journal of Advanced Nursing, 62(3), 373-380. http://dx.doi.org/10.1111/j.1365-2648.2007.04558.x

Plummer, M., \& Young, L. E. (2010). Grounded Theory and Feminist Inquiry: Revitalizing Links to the Past. Western Journal of Nursing Research, 32(3), 305-321.

Poortman, A., \& Van Der Lippe, T. (2009). Attitudes Toward Housework and Child Care and the Gendered Division of Labor. Journal of Marriage \& Family, 71(3), 526-541. http://dx.doi.org/10.1111/j.1741-3737.2009.00617.x

Rintala, T., Paavilainen, E., \& Åstedt-Kurki, P. (2014). Challenges in combining different data sets during analysis when using grounded theory. Nurse Researcher, 21(5), 14-18.

Shelton, B. A. \& John, D. (1996).The division of household labor.Annual Review of Sociology, 22, 299-322.

Švab, A., \&Humer, Ž. (2013). "I Only Have to Ask Him and He Does It..." Active Fatherhood and (Perceptions of) Division of Family Labour in Slovenia. Journal of Comparative Family Studies, 44(1), 57-78.

Tiefenthaler, T. (1997). Fertility and Family Time Allocation in the Philippines.Population and Development Review 23(2), 377-397.

Williams, S., \& Reid, M. (2007). A grounded theory approach to the phenomenon of pro-anorexia. Addiction Research \& Theory, 15(2), 141-152. http://dx.doi.org/10.1080/16066350601143239

Zimmerman, A., McDermott, M., \& Gould, C. M. (2009). The local is global: third wave feminism, peace, and social justice. Contemporary Justice Review, 12(1), 77-90. http://dx.doi.org/10.1080/10282580802681766

\section{(cc) $\mathrm{BY}$}

This work is licensed under a Creative Commons Attribution 3.0 License. 